\title{
New nummulite (Foraminiferida) species from the Eocene of Northern Oman
}

\author{
ANDREW RACEY \\ Geochem Group Limited, \\ Chester Street, \\ Saltney, \\ Chester, CH4 8RD
}

\begin{abstract}
Three new species of nummulites; Nummulites minutus sp. nov., N. omanensis sp. nov. and N. schaubi sp. nov., are described and illustrated from the Eocene of Northern Oman. N. omanensis sp. nov. and N. schaubi sp. nov. are shown to range from Early to Middle Lutetian whilst $N$. minutus sp. nov. ranges from Late Ypresian to Early Lutetian. N. minutus sp. nov. is far smaller in all major dimensions than any species of Nummulites previously described and if found in isolation would be assumed to be very primitive and probably dated as Late Palaeocene. However, N. minutus sp. nov. was found in association with an unreworked Lutetian fauna. The commonly held belief that proloculus size and test size are smallest in the most primitive (i.e. oldest) species must therefore be treated with some degree of caution. J. Micropalaeontol., 11 (2), 189-195, December 1992.
\end{abstract}

\section{INTRODUCTION}

During a detailed study of the nummulitid fauna of Northern Oman some sixty-six species of nummulitid, including 38 belonging to Nummulites, were identified, described and illustrated (Racey 1988, Racey, in press). Of these, three are new and constitute the basis of this paper. All three species were found in Early Lutetian shallow marine, ramp limestones of the Seeb Limestone Formation (formerly called the Dammam Formation, a term widely used throughout the Arabian Peninsula) at Wadi Rusayl in Northern Oman (Fig. 1). One of the species, N. minutus sp. nov. was also found in the southern foothills at Wadi Bani Khalid (Fig. 1). The associated nummulite and assiline fauna is shown in Fig. 2. Previous work on the Tertiary nummulitids comprises a single paper by Montenat et. al. (1977) who cited nineteen species of Nummulites and three of Assilina, of which only three species were illustrated and none described.

\section{SYSTEMATIC PALAEONTOLOGY}

For the purpose of this study the following generic definition (from Blondeau, 1972 and Schaub, 1981) has been used.

\section{Genus Nummulites Lamarck, 1801}

Involute, flattened lenticular to globular test; spiral laminae and chambers simple; often tightly coiled with many whorls; pronounced alar prolongations; septal filaments radial, meandrine or reticulate; trabeculae present. Microspheric generation (B-form) usually distinctly larger than megalospheric generation (A-form).

Age : Late Palaeocene/Early Eocene (Basal Ilerdian = Thanetian), from near base of Morozovella velascoensis Zone (P5) to Early Oligocene (uppermost Rupelian) top of Globigerina ampliapertura Zone (P20-21 boundary) (Cavalier \& Pomerol, 1986).

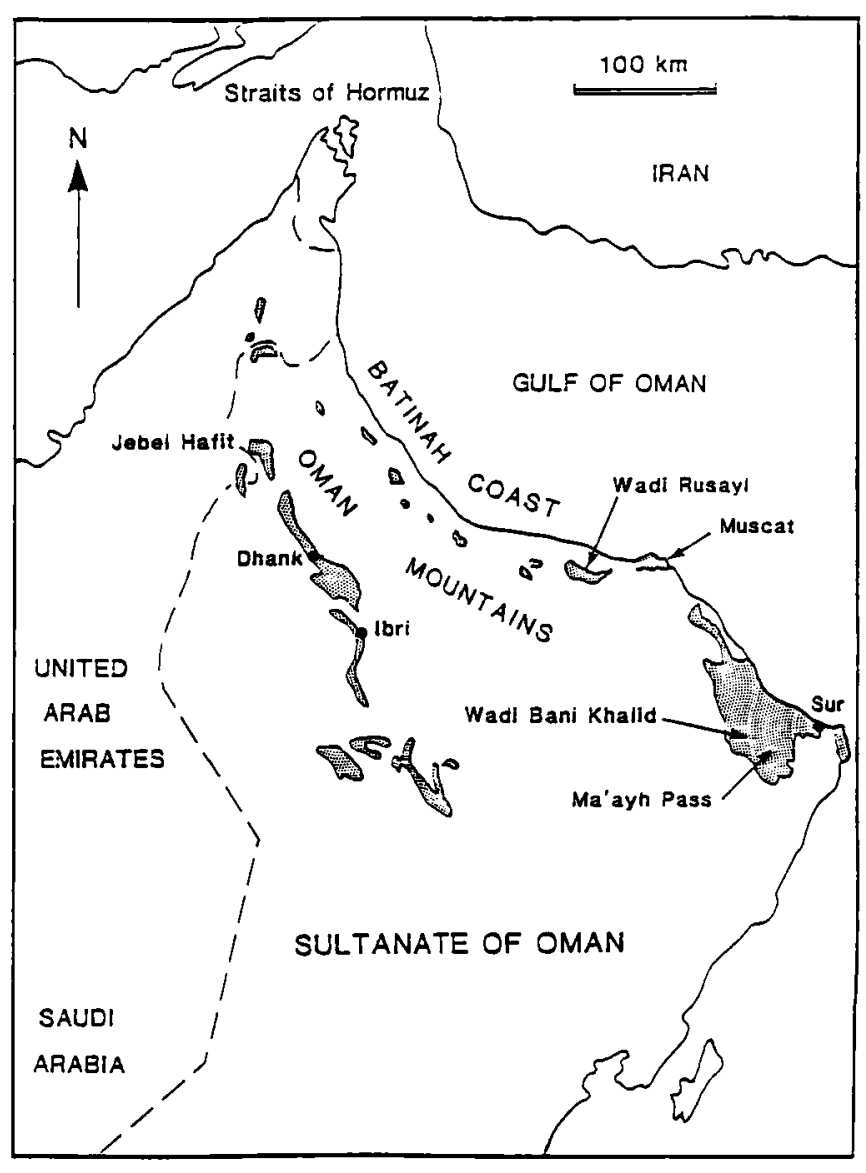

Fig. 1. Northern Oman: extent of Tertiary outcrop (stippled) 


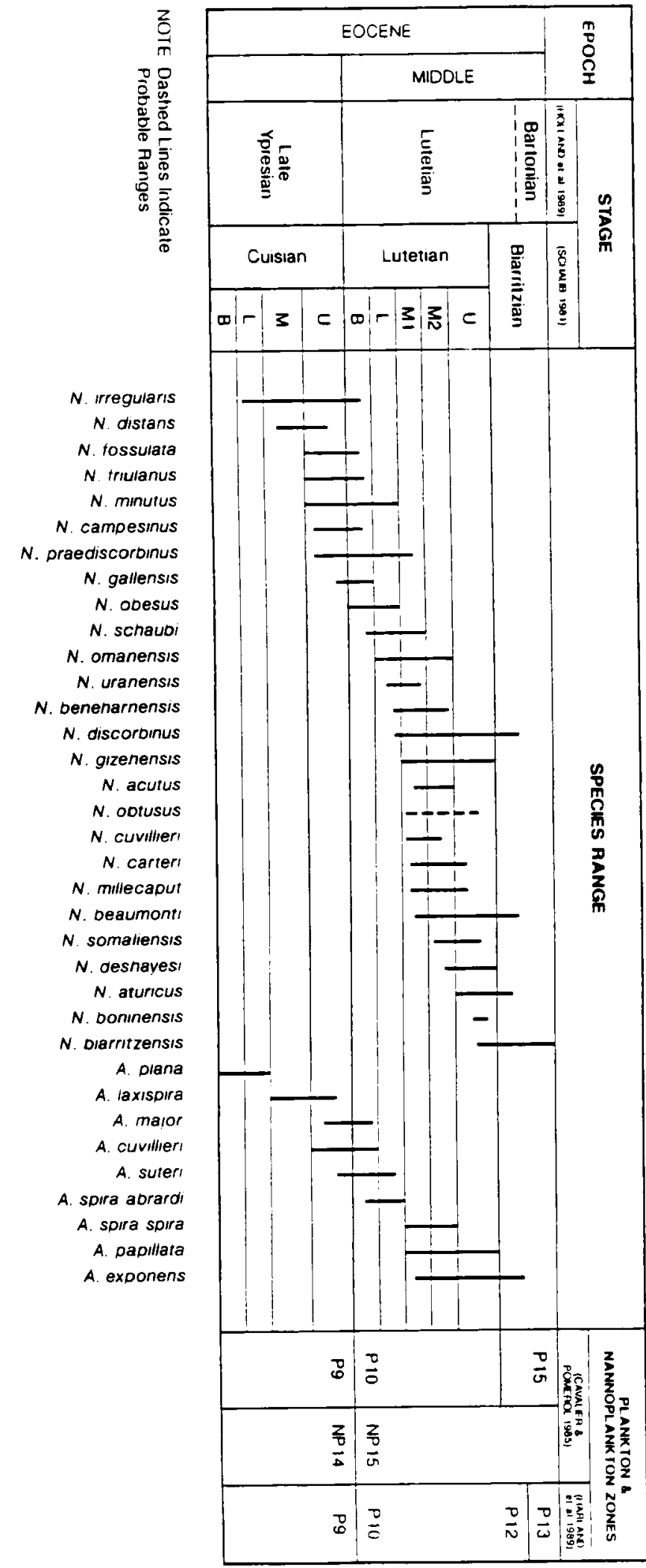

Fig. 2. Range chart for Oman nummulites and assilines found in association with the new species described herein.

\section{Material}

Species descriptions are based on matrix-free specimens from single assemblagesi.e. from a single locality. Figured specimens have been donated to the Department of Palaeontology, British Museum (Natural History) where they are catalogued under the following numbers : P52415, P52418 - P52420 (N. schaubi nov.sp.); P 52427 - P52428, P52430 - P52431 (N. omanensis sp. nov.) and P52422 \& P52424 (N. minutus sp. nov.).

\section{Description}

All descriptions are written in a standardised form. Under the heading. "Equatorial Section" there are three parameters labelled "Whorl", "Radius", and "Chambers". Whorl refers to the whorl number; Radius, to the distance to the whorl periphery in millimetres, and Chambers, to the number per whorl. Coiling diagrams for each species description are provided (figs. $3,5 \& 6$ ).

\section{Remarks}

This section is used to :- draw attention to the differences between morphologically similar species and to discuss taxonomic and nomenclatural problems.

\section{Faunal Associations and Stratigraphic Range}

Faunal associations refer to those taxa which occur with the new species in Oman, and are restricted to the associated nummulitids.

\section{SYSTEMATIC DESCRIPTIONS}

Superfamily Nummulitacea De Blainville, 1827. Family Nummulitidae De Blainville, 1825 Subfamily Nummulitidae Carpenter, 1850

Genus Nummulites Lamarck, 1801

Type species. Nummulites laevigatus (Bruguière) [= Camerina laevigata, Bruguière, 1792].

The type species was erected on the basis of material from several European localities, but was not figured. Schaub (1981) regarded the Paris Basin as the type area and his figures (op. cit. pl. 60, figs. 40,42-44) are accepted here as typical. Others on the same plate from Hungary, Italy and the Pyrenees, are closely similar.

\section{Nummulites minutus nov. sp.}

(Pl.1 figs. 6-7; Fig. 3)

Diagnosis : A very small species of Nummulites with a tiny proloculus, large polar pillar, simple radiating septal filaments and numerous small compact isometric chambers.

Derivation of name :- named on account of its small size

Holotype :- Pl. 1 fig 7 (BMNH no. P52424); Paratype Pl. 1 fig 6 (BMNH no. P52422)

Material. 4 isolated individuals ( 3 equatorial and 1 axial sections) and numerous specimens in random thin sections. All A-forms.

"Locality and Horizon". Lower part (Late Ypresian \& Early Lutetian) of Seeb Limestone Formation, Wadi Bani Khalid, Southern Oman Mountains, Northern Oman. Also known from the lower part (Early Lutetian) of the Seeb Limestone Formation in the road cutting at Wadi Rusayl near Jafnayn village in Northern Oman. 


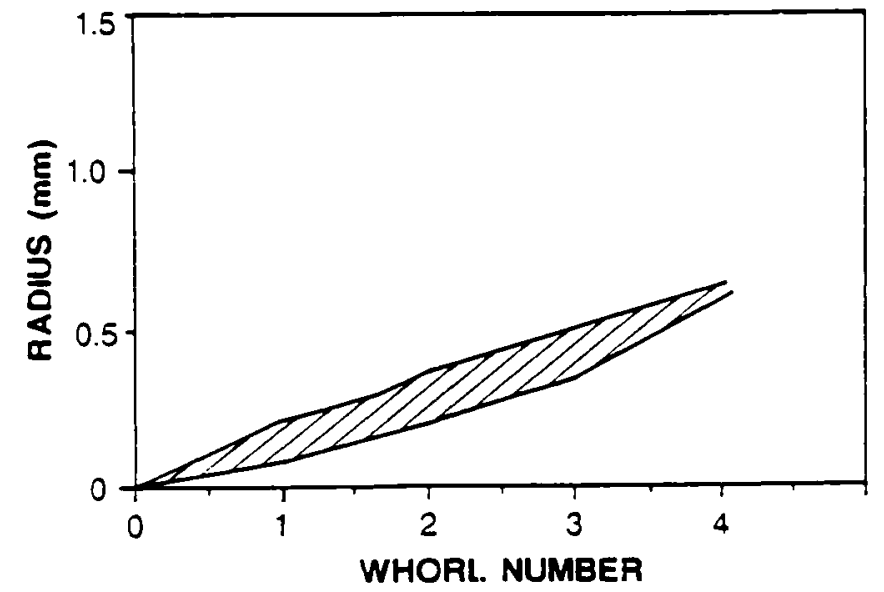

Fig. 3. N. minutus A-form coiling diagram

Description. B-Form. Not found.

A-form. Test very small, inflated lenticular, biconical with a rounded periphery. Septal filaments simple, radiating, narrowly spaced and gently curved; polar pillar present $(0.14$ $\mathrm{mm}$ in diameter at surface Pl.1 fig. 6). Spire regular opening uniformly (Fig. 3; Pl. 1, figs. 6 -7) ; chambers regular, compact isometric to slightly higher than long; septa straight to slightly inclined or curved. Marginal cord uniform $<1 / 3$ chamber height. Proloculus very small, 0.06 to $0.08 \mathrm{~mm}$ in diameter.

\begin{tabular}{|c|c|c|c|c|c|}
\hline \multicolumn{6}{|c|}{ Dimensions in mm (10 measured specimens) } \\
\hline & & \multicolumn{2}{|c|}{$\operatorname{Max}$} & Min & Mean \\
\hline Diameter & & \multicolumn{2}{|c|}{1.35} & 0.85 & 1.07 \\
\hline Thickness & & \multicolumn{2}{|c|}{0.70} & 0.52 & 0.62 \\
\hline $\mathrm{D} / \mathrm{T}$ & & \multicolumn{2}{|c|}{2.61} & 1.23 & 1.91 \\
\hline & \multicolumn{5}{|c|}{ Equatorial Section (mean values) } \\
\hline Whorl & 1 & 2 & 3 & 4 & \\
\hline Radius & 0.11 & 0.25 & 0.41 & 0.63 & \\
\hline Chambers & 6 & 15 & 19 & 24 & \\
\hline
\end{tabular}

Chamber height $/$ length in third whorl $=11 / 10$ microns, generally isometric

Remarks. A nummulite species smaller in all major dimensions than any described hitherto. (For a comparison with published species descriptions see Fig. 4). The small test size and small proloculussize suggest this species is very primitive. However, it was found in unreworked Lutetian sediments. Such small megalospheric specimens could easily have been disregarded or overlooked by earlier workers who tended to concentrate on the larger and more easily identifiable B-forms.

Faunal Associations and Stratigraphic Range

Found in Oman at Wadi Bani Khalid in association with $N$. friulanus, $N$. campesinus, $N$. fossulata, $N$. irregularis, $N$. praediscorbinus, N. obesus, Assilina maior, A.cuvillieri, A. laxispira and $A$. suteri and at Wadi Rusayl in association with $N$. gallensis, $N$. omanensis sp. nov., $N$. schaubi sp. nov. N. obesus, $N$. praediscorbinus, N. uranensis, $N$. beneharnensis, $A$. maior and $A$. spira abrardi which together indicate a Late Ypresian to Early Lutetian range for this species. (Fig. 2).
Nummulites omanensis sp. nov.

(Pl. 1 figs. 5, 8-10; Fig, 5)

Diagnosis. A species of Nummulites with a fairly tight spire, compact regularly inclined curved septa, and spirally arranged pillars.

Derivation of Name. Named after Oman the country from which this species is first described.

Holotype. Pl. 1 fig. 5(BMNH no P52427); Paratypes: Pl. 1 figs. 8 - 10 (BMNH nos. P52428, 52430, 52431).

Material. 27 individuals including 12 equatorial, 2 axial, 1 oblique sections and $12 \mathrm{~B}$-Form tests.

Locality and Horizon. Middle part (Early to Middle Lutetian) of Seeb Limestone Formation, Wadi Rusayl road cutting, near Jafnayn village Northern Oman.

Description. B-Form

Test lenticular with a rounded rarely flexed periphery. Septal filaments radiating, slightly flexed, tending to become slightly subreticulate towards the periphery; pillars arranged spirally on marginal cord (seen on decorticated specimens) and over remainder of test on and between the septal filaments. Spire regular, loosening slightly after the fifth/sixth whorl, and tightening in the last few whorls of larger individuals, forming a slight tripartition of the spire (Fig. 5; Pl.1; fig. 5); chambers subrectangular to slightly falciform, $1.5 \times$ higher than long in the early whorls becoming 2-2.5 $x$ longer than high in the outer whorls (Pl. 1 fig. 4); septa compact, regular, inclined and gently curved in the early whorls becoming more curved, inclined and widely spaced in the outer whorls. Marginal cord generally $1 / 2-1 / 3$ of chamber height, often thicker in the middle whorls (Pl.1, fig. 4).

\begin{tabular}{llll}
\multicolumn{5}{c}{ Dimensions in mm (27 measured specimens) } \\
& Max & Min & Mean \\
Diameter & 12.52 & 7.67 & 10.23 \\
Thickness & 4.14 & 2.70 & 3.53 \\
D/T & 3.02 & 2.81 & 2.92
\end{tabular}

Equatorial Section (mean values)

$\begin{array}{lllllllllll}\text { Whorl } & 1 & 2 & 3 & 4 & 5 & 6 & 7 & 8 & 9 & 10\end{array}$

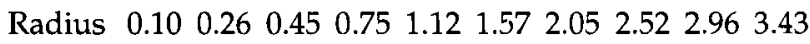

$\begin{array}{llllllllll}\text { Chambers } & 13 & 25 & 28 & 32 & 36 & 41 & 42 & 47 & 46\end{array}$

$\begin{array}{llllllll}\text { Whorl } & 11 & 12 & 13 & 14 & 15 & 16 & 17\end{array}$

Radius $\quad 3.854 .314 .675 .015 .235 .495 .58$

$\begin{array}{llllllll}\text { Chambers } & 49 & 49 & 49 & 46 & 45 & - & -\end{array}$

A-Form

Not Found

Remarks. The spiral arrangement of pillars, and the fairly compact, regularly inclined and curved septa with slightly falciform septa in the initial whorls suggest that this species belongs to the N. partschi Group sensu Schaub (1981). However, the spire is markedly tighter than in any other member of this group. In addition, the development of slight subreticulation and lengthening of the chambers in the outer whorls suggests partial affinities with the laevigatus and/or brongniarti groups of Schaub (1981). 


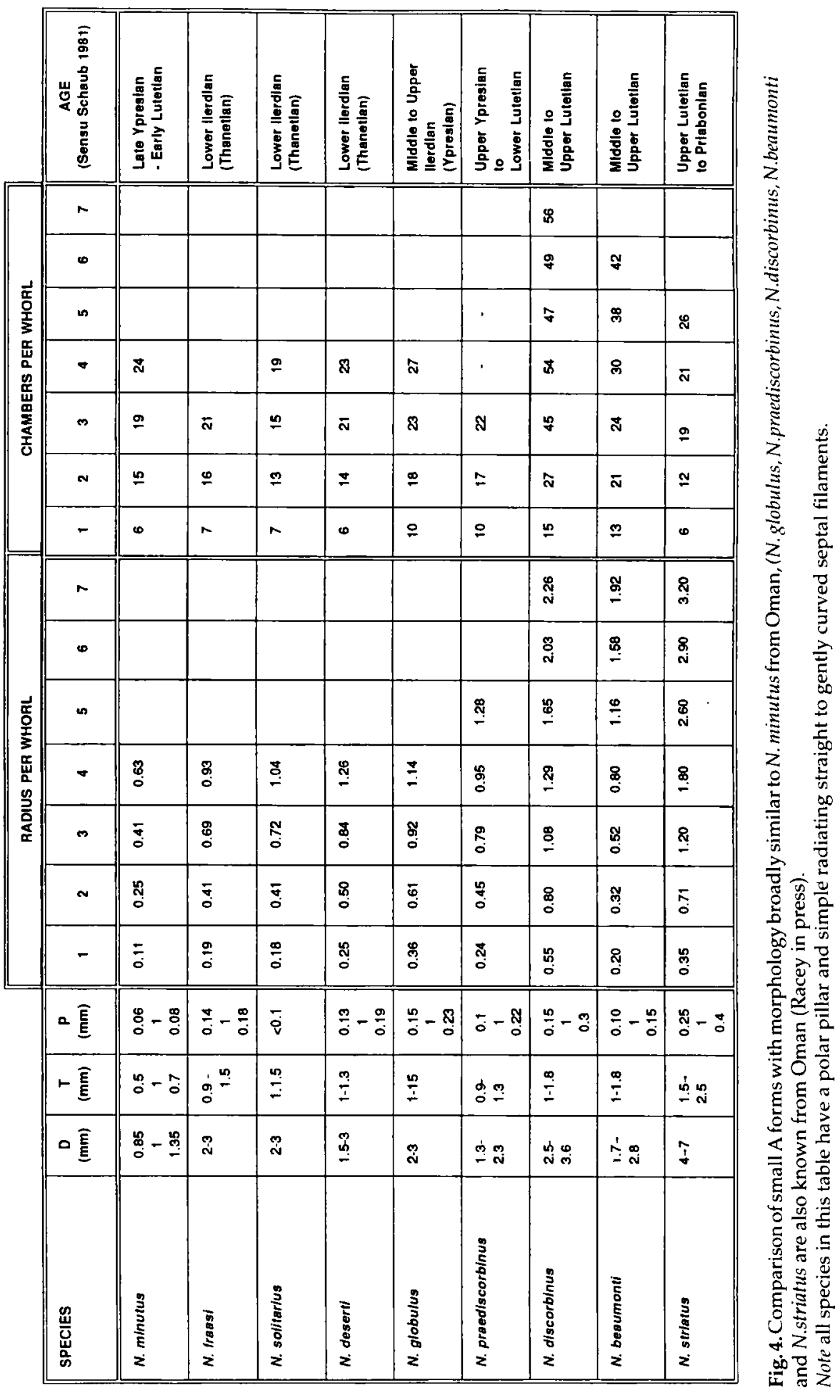

Explanation of Plate 1

Figs. 1-4. N. schaubi sp. nov. Fig. 1. B-form, near axial section (slide P. 52419, paratype), X5; Figs. 2-3. B-forms, equatorial section (slides P52418 \& P52415, paratypes), X6.5; Fig. 4. B-form, equatorial split specimen (slide P52420, holotype), X5.

Figs. 5, 8-10. N. omanensis sp. nov. Fig. 5. B-form, equatorial section (slide P52427, holotype), X7; Fig. 8. B-form, equatorial section (slide P52428, paratype), X7; Fig. 9. B-form, axial section, (slide P52431, paratype), X5; Fig. 10, B-form, oblique section, parallel to equatorial plane, note crude spiral arrangement of pillars, (slide P52430, paratype), $X 5$.

Figs 6-7. N. minutus sp. nov. Fig. 6. A-form, axial section, note large polar pillar (slide P 52422, paratype), X40; Fig. 7. A-form, equatorial section (slide P52424 holotype), X40. 


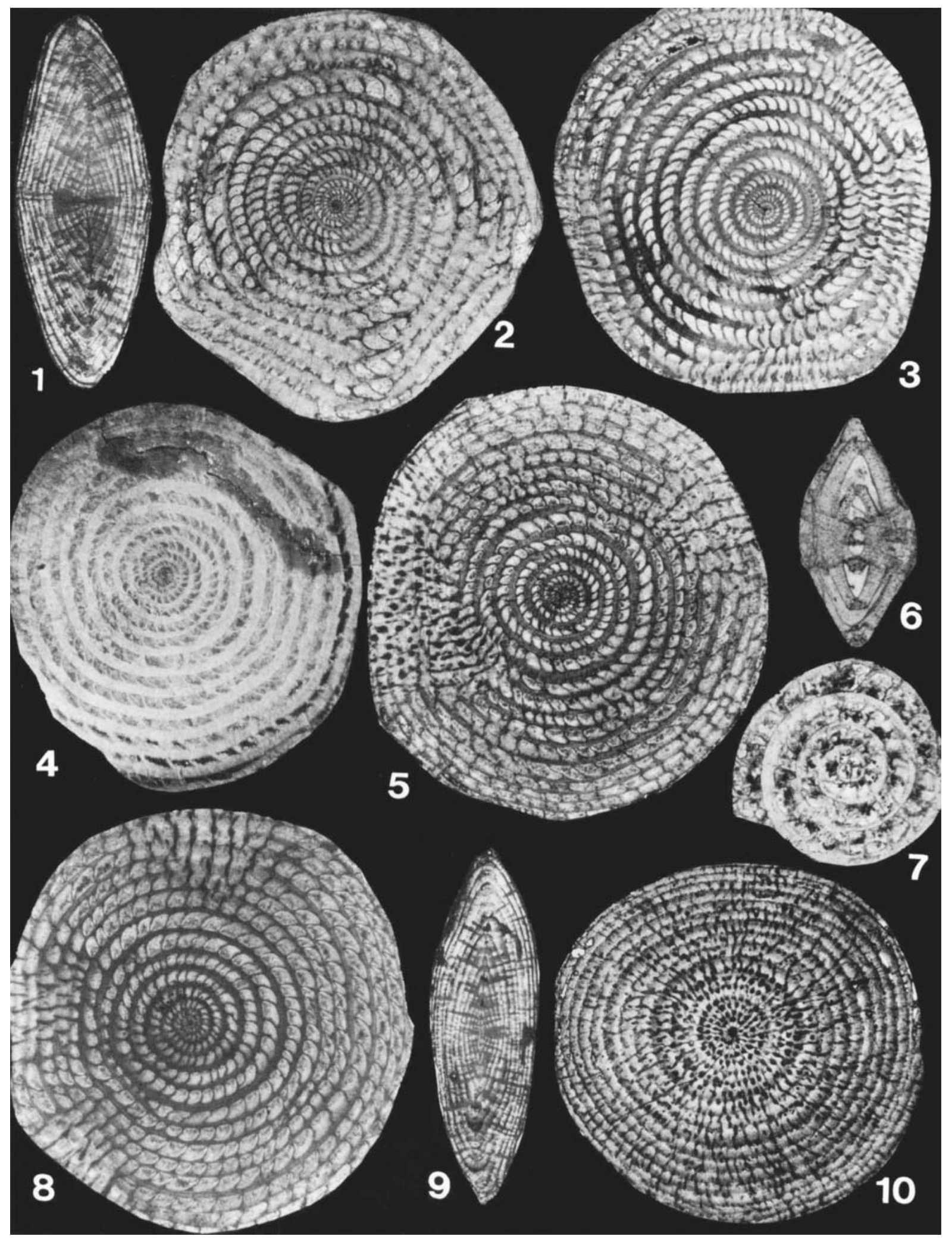




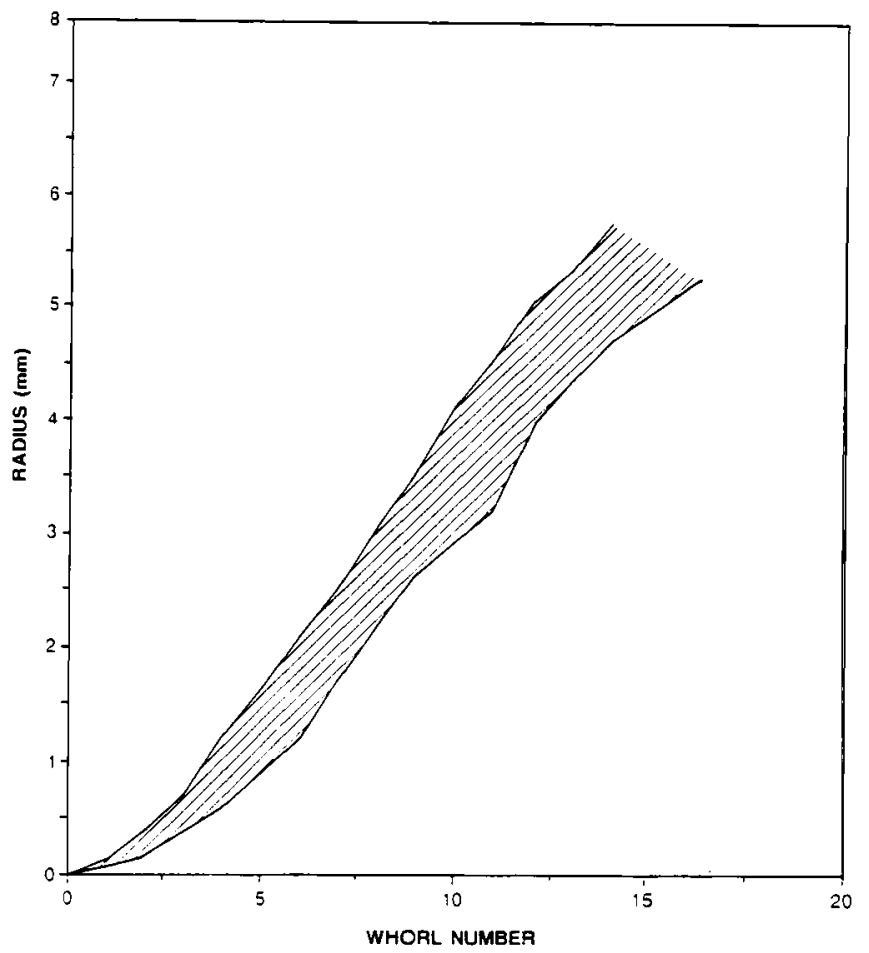

Fig. 5. Nummulites omanensis B-form coiling diagram

Faunal Associations and Stratigraphic Range. Found in Oman in association with Nummulites discorbinus, N. schaubi sp. nov. N.cuvillieri, N. beneharnensis, N. uranensis, N.obesus, N.gizehensis, Assilina spira, A. spira abrardi and $A$. papillata indicating an age range within the Early Lutetian to Middle Lutetian. (Fig. 2).

\section{Nummulites schaubi sp. nov.}

(Pl. 1 figs 1 - 4, Fig. 6)

Diagnosis. A species of Nummulites with a uniform tight spire, fairly numerous rectangular chambers which become progressively longer in the outer whorls.

Derivation of Name. Named in honour of Professor Hans Schaub (Basel) in recognition of his contribution to nummulitid biostratigraphy and taxonomy.

Holotype. Pl. 1 fig. 4. (BMNH no. P5240); Paratypes: Pl. 1 figs. 1 - 3. (BMNH nos. P52415, 52418, 52419).

Material. 23 individuals comprising 2 axial, 15 equatorial, 3 oblique sections and 2 matrix free B-Forms.

Locality and Horizon. Middle part (Early to Middle Lutetian) of Seeb Limestone Formation, Wadi Rusayl road cutting near Jafnayn village, Northern Oman.

Description. B-Form

Test flattened lenticular, with a fairly thin, rounded to sharp, slightly flexed periphery. Septal filamentsS-shaped to slightly swirling; pillars on and between septal filaments, occasionally elongated along them, less abundant towards the periphery. In axial section, pillars are long, thin and concentrated in the polar regions, rarely reaching the last whorl (Pl. 1, fig. 1). Spire uniform, tight and regular with occasional irregularities in the outermost whorls (Pl. 1, fig.2; Fig. 6); chambers regular, fairly numerous, initially 1.5-2 $\times$ higher than long, rectangular or slightly falciform becoming up to $2 \times$ longer than high after the tenth/eleventh whorl; septa compact, initially straight to slightly curved, less compact and more curved in the outer whorls. Marginal cord thick, up to $1 / 2$ chamber height.

\begin{tabular}{|c|c|c|c|}
\hline \multicolumn{4}{|c|}{ Dimensions in $m m$ ( 23 measured specimens) } \\
\hline $\operatorname{Max}$ & Min & Mean & \\
\hline Diameter & 16.04 & 9.32 & 12.68 \\
\hline Thickness & 4.62 & 2.40 & 3.31 \\
\hline $\mathrm{D} / \mathrm{T} \quad 5.63$ & 2.55 & 4.87 & \\
\hline
\end{tabular}

Equatorial Section (mean values)

$$
\begin{array}{lllllllllll}
\text { Whorl } & 1 & 2 & 3 & 4 & 5 & 6 & 7 & 8 & 9 & 10 \\
\text { Radius } & 0.09 & 0.20 & 0.40 & 0.72 & 1.13 & 1.61 & 2.12 & 2.71 & 3.34 & 3.93 \\
\text { Chambers - } & 17 & 22 & 24 & 24 & 32 & 40 & 41 & 37 & 42 \\
& & & & & & & & & & \\
\text { Whorl } 11 & 12 & 13 & 14 & 15 & 16 & & & & \\
\text { Radius } 4.5 & 5.19 & 5.85 & 6.51 & 6.78 & 7.16 & & & & \\
\text { Chambers } 48 & 52 & 61 & 59 & - & - & & &
\end{array}
$$

A-Form

Not Found

Remarks. These specimens appear to be more evolved species of N. arnii as figured by Schaub (1981, pl. 47, figs. 31-37) from the basal Lutetian of Libya. They differ from $N$. arnii in that they are larger, possess more whorls and have a tighter spire.

Faunal Associations and Stratigraphic Range. The probable precursor to this species, N. arnii, has been recorded from the Basal Lutetian of the Syrte Basin in Libya. N. schaubi sp. nov. is found in Oman in association with $N$. beneharnensis, $N$. gizehensis, N. obesus, N. discorbinus, N. omanensis, sp. nov., $N$.

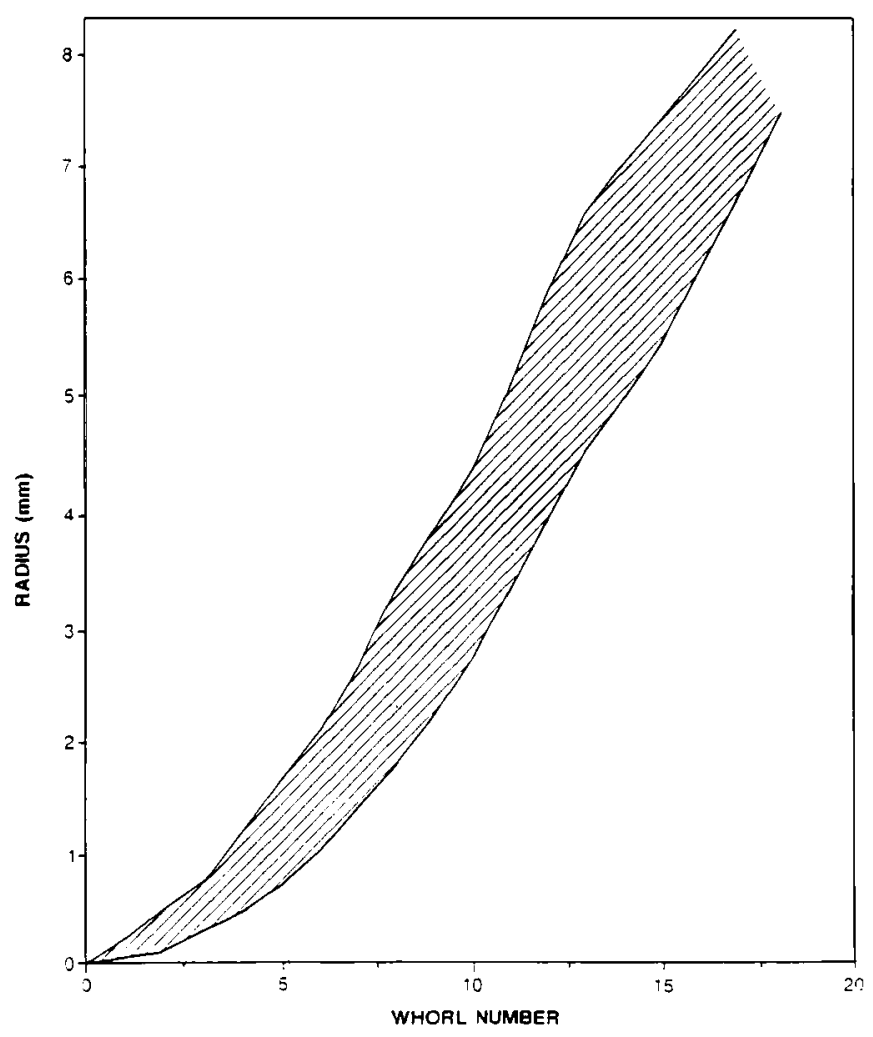

Fig. 6. Nummulites shaubi B-form coiling diagram 
cuvillieri, Assilina spira abrardi, A papillata, A. spira indicating a late Lower Lutetian to early Middle 1 Lutetian age (Fig. 2).

\section{DISCUSSION}

1. Three new species of nummulite are described from the Early to Middle Lutetian part of the Seeb Limestone of Northern Oman.

2. In terms of the palaeobiogeographic importance of these new species and the associated nummulitid fauna, the following points are of note :

a) The Middle Eocene nummulitid fauna of Northern Oman shows a pronounced mixing between Western Tethyan and Eastern Tethyan species and, more exceptionally Indo-Pacific species. This mixing became most pronounced in the latter part of the Middle Eocene (Late Lutetian) (for a full discussion see Racey, in press and Racey 1988).

(b) It is interesting to note that the new, possibly endemic species described herein developed during the period of maximum species diversity development in the Oman nummulitid fauna, immediately prior to the pronounced mixing of Eastern and Western Tethyan and Indo-Pacific faunas which followed in the Late Lutetian.

3. The presence of $N$. minutus sp. nov. in unreworked Lutetian sediments is difficult to explain in the context of the generally accepted views of the evolutionary development of the genus. It is easy enough to understand how such a small species could easily be "overlooked", in that it is common practice to use the larger more easily recognised and better described B-forms for the biostratigraphic dating of nummulite-bearing sequences. $N$. minutus sp. nov. is smaller in all major dimensions by a factor of approximately $50 \%$ when compared with the smallest (most primitive) species previously described. The presence of this small new species from the Lutetian raises a number of interesting questions:

(a) Could this new species be a stunted variety of morphologically similar Lutetian species such as $N$.discorbinus? This is unlikely since none of the associated nummulite species show any evidence for stunting, with the palaeoenvironment suggesting optimal conditions for nummulite development both in terms of numbers and species diversity.

(b) Could N. minutus sp. nov. be part of a trimorphic life cycle of another already described nummulite species as observed for the living nummulitid Heterostegina depressa by Rottger (1987)?. Trimorphism in the fossil record would be virtually impossible to detect and to the best of the author's knowledge has not been described for any fossil nummulitid; consequently it will not be discussed further.

(c) Could N. minutus sp. nov. be a true "primitive" species which has simply not evolved? Although sufficiently morphologically similar to primitive Late Palaeocene species to have been potentially ancestral to such species, $N$. minutus has not been found in Oman below the Late Ypresian (or above the Early Lutetian) despite extensive studies of nummulite-bearing Late Palaeocene to Priabonian limestones. The range of this species given herein as Late Ypresian to Early Lutetian is therefore considered to beclose to the probable absolute range for the species (at least in Oman).

(d) Are we simply wrong to assume that such small species are primitive and therefore misguided in assuming that the two dominant trends in nummulite evolution from Late Palaeocene to end Middle Eocene are an increase in test size of B-forms and an increase in proloculus size in A-forms (with a general, but not so marked increase in test size)?. Such generalizations only really hold for individual lineages and cannot therefore be applied to all species of similar age. For example, A-forms of $N$. discorbinus ( $N$. rotalarius lineage) from the Middle Lutetian of Oman have test diameters of 2.5$3.6 \mathrm{~mm}$ and proloculus diameters of $0.15-0.30 \mathrm{~mm}$ whilst coeval $N$. gizhensis ( $N$. partschi lineage) A-forms, from the same bed, have test diameters of $3.67-6.41 \mathrm{~mm}$ and proloculus diameters of $0.66-1.25 \mathrm{~mm}$. N. minutus sp. nov. cannot be easily incorporated in any existing lineages and therefore is most likely to be part of a new lineage.

\section{ACKNOWLEDGEMENTS}

Dr. C. G. Adams and Dr. J. E. Whittaker British Museum (Natural History), London are thanked for their support and encouragement. Dr. J.E. Whittaker is also thanked for his comments on the original manuscript. The work was completed while the author was in receipt of a NERC/CASE award to study at the British Museum (Natural History). Hilary Hatch (Geochem Group Limited) is thanked for her secretarial assistance.

\section{Manuscript received May 1992 \\ Manuscript accepted July 1992}

\section{REFERENCES}

Blondeau, A. 1972. Les Nummulites, Paris, Vuibert, 254 pp.

Cavalier, C. \& Pomerol, C. 1986. Stratigraphy of the Palaeogene. Bull. Soc. géol. Fr., 8, 225-265.

Montenant, C., Blondeau, A., Bizon, G., Perreau, M., Raju, D.S.N., \& Roman, J. 1977. Premier apercu du Tertiare d'Oman (Péninsule arabique orientale). Bull Soc. géol. Fr., 19, 1285-1295.

Racey, A. 1988. Nummulitid Biostratigraphy and Palacogene Palaeoenvironments, Sultanate of Oman, PhD thesis, University of London, 510pp. [Unpublished].

Racey, A. in press. Biostratigraphy and Palaeobiogeographic significance of Tertiary Nummulites (Foraminifera) from Northern Oman. BMS Special Publication: Micropalneontologyand Hydrocarbon Exploration in the Middle East, London, Chapman \& Hall.

Rötger, R. 1987. Heterostegina apogama a new Holocene nummulitid (Protozoa, Foraminiferida) from Hawaii. J. foramin. Res., 17, 187 189.

Schaub, H. 1981. Nummulites et Assilines de la Tethys Palaeogene: Taxinomie, phylogenese et biostratigraphie. Abh. Schweiz, Palaönt., Geo., 104-106, 1-236. 